\title{
Determination of the Appropriate Quality of Life Scale for Patients with Rheumatoid Arthritis and Osteoarthritis
}

\section{Romatoid Artrit ve Osteoartritli Hastalar İçin Uygun Yaşam Kalitesi Ölçeğinin Belirlenmesi}

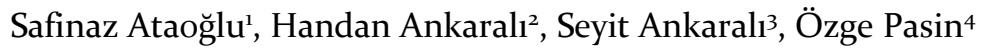 \\ 'Düzce University, Medical Faculty, Physical Medicine and Rehabilitation Department \\ ${ }^{2}$ İstanbul Medeniyet University, Medical Faculty, Biostatistics Department \\ 3Istanbul Medeniyet University, Medical Faculty, Physiology Department \\ ${ }^{4}$ Istanbul University, Medical Faculty, Biostatistics Department
}

\begin{abstract}
Objectives: A large number of quality-of-life scales are used to assess the effects of various diseases on the quality of life. The most commonly used scale is the SF-36 quality of life scale. However, in recent years various versions and shorter forms of this scale have been developed. Quality of life scales, which can be applied in a shorter period and which can be interpreted more easily and which produce reliable and valid results, are preferred more. The purpose of this study is to determine the scales that measure the quality of life better and practical would be appropriate in Osteoarthritis (OA) and Rheumatoid Arthritis (RA).

Materials and Methods: Cronbach's alpha coefficient was used for the internal consistency of the scales, the intra-class correlation coefficient was used for relations between item-total score, and the agreement between SF-36 scale and other short forms, and also the Spearman Rank correlation analysis were used for evaluation of the relationships between the total scores of the scales. The criterion validity of the short forms (SF) of the quality of life scale were investigated by using WHOQOLBref and QuickDASH scales.

Results: The internal consistency of the scales were found to be at a quite good level. In OA patients, the highest agreement in Physical Function, Bodily Pain and Vitality sub-dimensions of the SF-6D scale were found. On the other hand, Physical Role, Emotional Role and General Health sub-dimensions in the SF-12 scale have higher agreement. In RA, Bodily Pain and Vitality sub-dimensions of the SF-6D were found to have higher agreement, and the SF-12 scale have higher agreement in the Physical Function, Physical Role, General Health and Emotional Role. Moreover, in both disease groups, the validity of SF-12 and SF-6D scales was similar to each other in many conditions, and better than the SF-8 scale. Conclusion: According to the results, SF-12 or SF-6D scales could be used effectively to evaluate the quality of life in RA and OA patients.

Key words: Rheumatic diseases, SF-36, SF-12, SF-8, SF-6D, QuickDASH, WHOQOLBref
\end{abstract}

\section{Öz}

Amaç: Çeşitli hastalıkların yaşam kalitesi üzerindeki etkilerini değerlendirmek için çok sayıda yaşam kalitesi ölçeği kullanılmaktadır. Bunlar arasında en yaygın kullanılan ölçek, SF-36 yaşam kalitesi ölçeğidir. Bununla birlikte, son yıllarda bu ölçeğin çeşitli versiyonları ve daha kısa formları geliștirilmiştir. Daha kısa sürede uygulanabilen, daha kolay yorumlanabilen, güvenilir ve geçerli sonuçlar veren yașam kalitesi ölçekleri daha fazla tercih edilmektedir. Bu çalıșmanın amacı, Osteoartrit (OA) ve Romatoid Artrit (RA) 'da yaşam kalitesini daha iyi ve kısa sürede ölçen ölçekleri belirlemektir.

Materyal ve Metot: Ölçeklerin iç tutarlılı̆̆ için Cronbach alfa katsayısı, madde-toplam puan ilişkileri ve SF-12, SF-8 ve SF-6D ölçek puanları ile SF-36 ölçek puanları arasındaki uyum sınıf içi korelasyon katsayısı ve ölçeklerin toplam puanları arasındaki ilişkilerin değerlendirilmesinde Spearman Rank korelasyon analizi kullanıldı. SF ölçeklerinin kriter geçerliliğini incelemek için WHOQOLBref ve QuickDASH ölçekleri kullanıldı.

Bulgular: Her iki hastalık grubunda da ölçeklerin iç tutarlılığının oldukça iyi düzeyde bulundu. OA hastalarında, SF-6D ölçeğinin Fiziksel Fonksiyon, Vücut Ağrısı ve Canlılık alt boyutlarına ait uyumu en 
yüksek bulundu. Buna karşın SF-12 ölçeğinin Fiziksel Rol, Duygusal Rol ve Genel Sağlık algısı alt boyutlarının uyumunun daha yüksek olduğu belirlendi. RA hastalarında SF-6D ölçeğinin Canlılık ve Vücut Ağrısı alt boyutlarının uyumu, SF-12 ölçeğinin ise Fiziksel Fonksiyon, Fiziksel Rol, Genel Sağlık Algısı ve Duygusal Rol uyumu daha yüksek bulundu. Ayrıca her iki hastalık grubunda ve birçok alt boyutta SF-12 ve SF-6D ölçeklerinin geçerliliği birbirine benzer ve SF-8 ölçeğine göre daha iyi bulundu.

Sonuç: Elde edilen bulgular doğrultusunda, RA ve OA hastalarında yaşam kalitesini değerlendirmek için SF-12 veya SF-6D ölçeklerinden etkin bir șekilde yararlanılabileceği görüldü.

Anahtar kelimeler: Romatolojik hastalıklar, SF-36, SF-12, SF-8, SF-6D, QuickDASH, WHOQOLBref

Correspondence / Yazışma Adresi:

Dr. Özge Pasin

İstanbul Üniversitesi Tıp Fakültesi Biyoistatistik AD, 340oo, Fatih / İstanbul

e-mail: ozgepasingo@yahoo.com.tr

Date of submission: 12.04.2018

Date of admission: 08.11.2018

\section{Introduction}

Quality of life can be defined as the emotional and personal response to the difference between the activities that a patient can and should normally do. ${ }^{1}$ It is not a quantity that is measured by medical techniques and laboratory procedures but a quality experienced subjectively. It is an important criterion in determining the effects of chronic diseases such as rheumatic diseases, in following up the treatment, and in patient satisfaction. Among these diseases, osteoarthritis (OA) which is characterized by the damage of joint cartilage and subchondral bone is the most common joint disease and causes a considerable disability. ${ }^{2-5}$ Rheumatoid arthritis (RA) is a chronic systemic inflammatory disease that primarily affects joints. ${ }^{4}$ It causes progressive damage and functional restrictions in cartilage and bones. ${ }^{5}$ These diseases impair quality of life in both emotional and physical conditions by causing difficulties in daily activities and in functional capacity of the patient. Because of the reason, quality of life scales are often employed in patient follow up.

Scales, that are developed to measure quality of life, include physical and occupational functions, social interactions, psychological and financial conditions. There are several scales in literature that are used for this purpose. Among these scales, the one that is used widely in medical areas is "Short Form Quality of Life Scale" (SF-36v2). ${ }^{6}$ It is composed of 36 items and 8 sub-dimensions shortened from 120 items and it measures health conditions both in positive and negative aspects. This form has a shorter version called SF-12 scale composed of 8 sub-dimensions and 8 items, another scale called SF- 8 scale that excludes mental health and composes of 7 dimensions and 8 items and the last one called SF-6D scale excluding 2 dimensions and including 6 dimensions and 11 items. $7^{-9}$ WHOQOLBref Scale developed by World Health Organization (WHO) and composed of 27 items and 4 sub dimensions and QuickDASH Scale that gives quick results, composes of 11 items but evaluates only 1 dimension are also used for this purpose. $^{10-11}$

In rheumatic patients, tests that give the quickest and the most accurate results matter. Since it takes a lot of time answering 36 items in SF-36v2 scale, a shorter scale would be 
Determination of the Appropriate Quality of Life Scale for Patients with Rheumatoid Arthritis and Osteoarthritis

more satisfying both for patients and doctors. The quickest and the most accurate scales might differ according to the disease in question.

The purpose of this study to evaluate quality of life in RA and OA patients and determine the scales that measure quality of life quickly and accurately. In addition, we aim to find out scales that are mentioned in the literature but rarely used and cannot be found in our country. We also aim to find out the ones that are composed of less items than SF-36v2 scales, give faster results and provide data as valuable as SF-36v2 scale. In this way, we will be able to calculate the reliability and validity of SF-12, SF-8 and SF-6D forms.

\section{Materials and Methods}

\section{Sample and Sampling}

This is a cross-sectional scale study. 222 patients who consulted Duzce University, School of Medicine's Physical Medicine and Rehabilitation Outpatient Clinic between January 2016 and December 2016 were included in the study. 165 of the patients were OA patients and the 57 of them were RA patients as defined by American College of Rheumatology (ACR). All of the patients volunteered for the study. Approval was received from the Non-Invasive Clinical Trials Ethics Committee of Duzce University for the study before the initiation of data collection. The data were collected by face to face interview between the physician and the patient.

Mean age of OA patients was $54.50 \pm 15.70$ (18-97) and mean age of RA patients were $46.90 \pm 15.00(17-77) .116$ of the OA patients were female $(116 / 165=70.30 \%)$ and 40 of the RA patients $(40 / 57=70.20 \%)$ were female.

\section{Scales for Quality of Life}

SF-36v2, SF-12, SF-6D, WHOQOLBref and QuickDASH scale forms were filled on a face to face session. Sub dimensions of SF-36v2, SF-12, SF-8 and SF-6D scales are Physical function (PF), Role physical (RP), Bodily Pain (BP), General perception of health (GH), Vitality (VT), Social Function (SF), Role emotional (RE), Mental health (MH). Number of items and item coding in SF scales are shown in Table 1. The Table's columns display original items numbers in different SF scale forms. SF-36v2 short form's shorter version SF-12 is composed of 12 items and 8 sub dimensions. SF-8 is composed of 7 dimensions (does not include mental health sub dimension) and 8 items. SF-6D is composed of 6 dimensions and 11 items. It doesn't have GH dimension. RE\&RP dimension is united as Role Participation. So, this dimension evaluates both RE and RP with one items from each dimension.

The score calculations that belong to the sub dimensions of SF-12, SF-8, SF-6D scales and the item numbers that correspond to the items in SF-36v2 scale are given in Table 2. SF scales don't have grand total scores. Potential raw score is the difference between the highest and the lowest values of the calculated score. It is called score range in short. Calculation formula of each sub dimension of each scale is as follows:

Scale sub dimension score $=$ raw score-the lovest score $/$ possible raw score $\mathrm{x} 100$ 
Determination of the Appropriate Quality of Life Scale for Patients with Rheumatoid Arthritis and Osteoarthritis

Table 1. Features of SF Scales*

\begin{tabular}{|c|c|c|c|c|c|c|}
\hline \multirow{2}{*}{$\begin{array}{l}\text { Summary } \\
\text { Measures }\end{array}$} & \multirow{2}{*}{$\begin{array}{l}\text { Sub- } \\
\text { Dimension }\end{array}$} & SF-36v2 & SF-12 & SF-8 & SF-6D & \multirow{2}{*}{$\begin{array}{l}\text { New coding of items after data } \\
\text { collection }\end{array}$} \\
\hline & & \multicolumn{4}{|c|}{$\begin{array}{l}\text { Original item no on the } \\
\text { forms }\end{array}$} & \\
\hline \multirow{21}{*}{ PCS } & \multirow{10}{*}{$\mathbf{P F}$} & $3 a$ & & & $1 \mathrm{a}$ & \multirow{10}{*}{$\begin{array}{l}\text { All options get "1-2-3" codes like in original } \\
\text { form. } \\
\text { Only in the SF-8 scale is the item-2 } \\
\text { reduced from } 5 \text { options to } 3 \text { options and it } \\
\text { was reversed. So it was likened to other } \\
\text { items in PF sub dimension. }\end{array}$} \\
\hline & & $3 \mathrm{~b}$ & $2 a$ & & $1 b$ & \\
\hline & & $3 \mathrm{C}$ & & & & \\
\hline & & $3 d$ & $2 \mathrm{~b}$ & & & \\
\hline & & $3 e$ & & 2 & & \\
\hline & & $3 f$ & & & & \\
\hline & & 39 & & & & \\
\hline & & $3 \mathrm{~h}$ & & & & \\
\hline & & $3 \mathrm{i}$ & & & & \\
\hline & & $3 \mathrm{j}$ & & & $1 \mathrm{C}$ & \\
\hline & \multirow[b]{4}{*}{$\mathbf{R P}$} & $4 a$ & & & & \multirow{4}{*}{$\begin{array}{l}\text { All options get "1-2" codes like in original } \\
\text { form. } \\
\text { Only in the SF- } 8 \text { scale is the item-3 } \\
\text { reduced from } 5 \text { options to } 3 \text { options and } \\
\text { SF-6D scale is the item-2 reduced from } 6 \\
\text { options to } 2 \text { options and they was } \\
\text { reversed. So it was likened to other items } \\
\text { in RP sub dimension. }\end{array}$} \\
\hline & & $4 \mathrm{~b}$ & $3 a$ & & & \\
\hline & & $4 C$ & $3 \mathrm{~b}$ & & 2 & \\
\hline & & $4 d$ & & 3 & & \\
\hline & & 7 & & 4 & 4 & $\begin{array}{l}a=1 \text { to } 6, b=2 \text { to } 5.4, c=3 \text { to } 4.2, d=4 \text { to } 3.1 \text {, } \\
e=5 \text { to } 2.2, f=6 \text { to } 1\end{array}$ \\
\hline & BP & 8 & 5 & & 5 & $\begin{array}{l}\mathrm{a}=1 \text { to } 5, \mathrm{~b}=2 \text { to } 4, \mathrm{c}=3 \text { to } 3, \mathrm{~d}=4 \text { to } 2, \mathrm{e}=5 \text { to } \\
1 \\
\text { (The last two options of the } 5^{\text {th }} \text { item on the } \\
\text { SF-6D scale were combined because of the } \\
\text { same meaning and the number of options } \\
\text { was reduced from } 6 \text { to } 5 \text { ) }\end{array}$ \\
\hline & \multirow{5}{*}{ GH } & 1 & 1 & 1 & & $\begin{array}{l}\mathrm{a}=1 \text { to } 5, \mathrm{~b}=2 \text { to } 4.4, \mathrm{c}=3 \text { to } 3.4, \mathrm{~d}=4 \text { to } 2 \text {, } \\
\mathrm{e}=5 \text { to } 1 \\
\text { (The number of options of the } 1^{\text {th }} \text { item on } \\
\text { the SF- } 8 \text { scale was reduced from } 6 \text { to } 5 \text { ) }\end{array}$ \\
\hline & & $11 \mathrm{a}$ & & & & $\mathrm{a}=1, \mathrm{~b}=2, \mathrm{c}=3, \mathrm{~d}=4, \mathrm{e}=5$ (original) \\
\hline & & $11 \mathrm{~b}$ & & & & $\mathrm{a}=5, \mathrm{~b}=4, \mathrm{c}=3, \mathrm{~d}=2, \mathrm{e}=1$ (revised) \\
\hline & & $11 \mathrm{C}$ & & & & $a=1, b=2, c=3, d=4, e=5$ (original) \\
\hline & & 11d & & & & $a=5, b=4, c=3, d=2, e=1$ (revised) \\
\hline \multirow{4}{*}{ MCS } & \multirow{4}{*}{ VT } & $9 a$ & & 5 & & $\begin{array}{l}\mathrm{a}=1 \text { to } 6, \mathrm{~b}=2 \text { to } 5, \mathrm{c}=3 \text { to } 4, \mathrm{~d}=4 \text { to } 3, \mathrm{e}=5 \text { to } \\
2, \mathrm{f}=6 \text { to } 1 \\
\text { (In the original form of the } \mathrm{SF}-8 \text {, the } 5 \\
\text { options in the item } 5 \text { were arranged as } 6 \\
\text { options) }\end{array}$ \\
\hline & & 9e & $6 b$ & & $6 b$ & $\begin{array}{l}\mathrm{a}=1 \text { to } 6, \mathrm{~b}=2 \text { to } 5, \mathrm{c}=3 \text { to } 4, \mathrm{~d}=4 \text { to } 3, \mathrm{e}=5 \text { to } \\
2, \mathrm{f}=6 \text { to } 1 \\
\text { (In the original form of the } S F-12 \text {, the } 5 \\
\text { options in the item } 6 \mathrm{~b} \text { were arranged as } 6 \text { ) }\end{array}$ \\
\hline & & $9 g$ & & & & $\begin{array}{l}a=1 \text { to } 1, b=2 \text { to } 2, c=3 \text { to } 3, d=4 \text { to } 4, e=5 \text { to } \\
5, f=6 \text { to } 6\end{array}$ \\
\hline & & $9 \mathrm{i}$ & & & & $\mathrm{a}=1$ to $1, \mathrm{~b}=2$ to $2, \mathrm{c}=3$ to $3, \mathrm{~d}=4$ to $4, \mathrm{e}=5$ to \\
\hline
\end{tabular}


Determination of the Appropriate Quality of Life Scale for Patients with Rheumatoid Arthritis and Osteoarthritis

\begin{tabular}{|c|c|c|c|c|c|}
\hline & & & & & $5, f=6$ to 6 \\
\hline \multirow[t]{2}{*}{ SF } & 6 & 7 & 6 & & $\begin{array}{l}\mathrm{a}=1 \text { to } 5, \mathrm{~b}=2 \text { to } 4, \mathrm{c}=3 \text { to } 3, \mathrm{~d}=4 \text { to } 2, \mathrm{e}=5 \text { to } \\
1 \\
\text { (revised) }\end{array}$ \\
\hline & 10 & & 8 & 7 & $a=1$ to $1, b=2$ to $2, c=3$ to $3, d=4$ to $4, e=5$ to \\
\hline \multirow[b]{3}{*}{$\mathrm{RE}$} & $5 \mathrm{a}$ & & & & \multirow{3}{*}{$\begin{array}{l}\text { All options get "1-2" codes like in original } \\
\text { form. } \\
\text { (The answers to item } 3 \text { of SF-6D scale and } \\
\text { and the answers to item } 7 \text { of SF- } 8 \text { are } \\
\text { reduced to only two options as "yes" and } \\
\text { "no") }\end{array}$} \\
\hline & $5 \mathrm{~b}$ & $4 a$ & 7 & 3 & \\
\hline & $5 \mathrm{C}$ & $4 \mathrm{~b}$ & & & \\
\hline \multirow{5}{*}{ MH } & $9 b$ & & & $6 a$ & $\begin{array}{l}a=1 \text { to } 1, b=2 \text { to } 2, c=3 \text { to } 3, d=4 \text { to } 4, e=5 \text { to } \\
5, f=6 \text { to } 6\end{array}$ \\
\hline & $9 \mathrm{c}$ & & & & $\begin{array}{l}a=1 \text { to } 1, b=2 \text { to } 2, c=3 \text { to } 3, d=4 \text { to } 4, e=5 \text { to } \\
5, f=6 \text { to } 6\end{array}$ \\
\hline & $9 d$ & $6 a$ & & & $\begin{array}{l}\mathrm{a}=1 \text { to } 6, \mathrm{~b}=2 \text { to } 5, \mathrm{c}=3 \text { to } 4, \mathrm{~d}=4 \text { to } 3, \mathrm{e}=5 \text { to } \\
2, \mathrm{f}=6 \text { to } 1 \\
\text { (In the original form of the } \mathrm{SF}-12 \text {, the } 5 \\
\text { options in the item } 6 \text { a were arranged as } 6 \text { ) }\end{array}$ \\
\hline & gf & $6 c$ & & $6 c$ & $\begin{array}{l}\mathrm{a}=1 \text { to } 1, \mathrm{~b}=2 \text { to } 2, \mathrm{c}=3 \text { to } 3, \mathrm{~d}=4 \text { to } 4, \mathrm{e}=5 \text { to } \\
5, \mathrm{f}=6 \text { to } 6 \\
\text { (In the original form of the SF-12, the } 5 \\
\text { options in the item } 6 \mathrm{c} \text { were arranged as } 6 \text { ) }\end{array}$ \\
\hline & $9 \mathrm{~h}$ & & & & $\begin{array}{l}a=1 \text { to } 6, b=2 \text { to } 5, c=3 \text { to } 4, d=4 \text { to } 3, e=5 \text { to } \\
2, f=6 \text { to } 1\end{array}$ \\
\hline & 2 & & & & \\
\hline
\end{tabular}

Table 2. Scale scores

\begin{tabular}{|c|c|c|c|c|}
\hline Scale & Sub-Dimension & $\begin{array}{c}S F-36 v 2 \text { item no and other } \\
\text { short form SF scales based } \\
\text { on } S F-36 \text { item no }\end{array}$ & $\begin{array}{l}\text { The } \\
\text { lowest } \\
\text { score }\end{array}$ & $\begin{array}{c}\text { Possible } \\
\text { Raw } \\
\text { Score }\end{array}$ \\
\hline \multirow{8}{*}{$S F-36 v 2$} & $\begin{array}{l}\text { General perception of } \\
\text { health }(\mathrm{GH})\end{array}$ & $1+11 a+11 b+11 c+11 d$ & 5 & 20 \\
\hline & Physical function (PF) & $\begin{array}{c}3 a+3 b+3 c+3 d+3 e+3 f+3 g+3 h+3 \\
i+3 j\end{array}$ & 10 & 20 \\
\hline & Role physical (RP) & $4 a+4 b+4 c+4 d$ & 4 & 4 \\
\hline & Role emotional (RE) & $5 a+5 b+5 c$ & 3 & 3 \\
\hline & Social function (SF) & $6+10$ & 2 & 8 \\
\hline & Bodily pain (BP) & $7+8$ & 2 & 10 \\
\hline & Mental health (MH) & $9 b+9 c+9 d+9 f+9 h$ & 5 & 25 \\
\hline & Vitality (VT) & $9 a+9 e+9 g+9 i$ & 4 & 20 \\
\hline \multirow{5}{*}{$S F-12$} & $\begin{array}{l}\text { General perception of } \\
\text { health }(\mathrm{GH})\end{array}$ & $1(1)$ & 1 & 4 \\
\hline & Physical function (PF) & $3 b+3 d(2 a+2 b)$ & 2 & 4 \\
\hline & Role physical (RP) & $4 b+4 c(3 a+3 b)$ & 2 & 2 \\
\hline & Role emotional (RE) & $5 b+5 c(4 a+4 b)$ & 2 & 2 \\
\hline & Social function (SF) & $6(7)$ & 1 & 4 \\
\hline
\end{tabular}


Determination of the Appropriate Quality of Life Scale for Patients with Rheumatoid Arthritis and Osteoarthritis

\begin{tabular}{|c|c|c|c|c|}
\hline & Bodily pain (BP) & $8(5)$ & 1 & 4 \\
\hline & Mental health (MH) & $9 d+9 f(6 a+6 c)$ & 2 & 10 \\
\hline & Vitality (VT) & 9e $(6 b)$ & 1 & 4 \\
\hline \multirow{8}{*}{$S F-8$} & $\begin{array}{l}\text { General perception of } \\
\text { health }(\mathrm{GH})\end{array}$ & $1(1)$ & 1 & 4 \\
\hline & Physical function (PF) & 3e (2) & 1 & 2 \\
\hline & Role physical (RP) & $4 d(3)$ & 1 & 1 \\
\hline & Role emotional (RE) & $5 \mathrm{~b}(7)$ & 1 & 1 \\
\hline & Social function (SF) & $6+10(6+8)$ & 2 & 8 \\
\hline & Bodily pain (BP) & $7(4)$ & 1 & 5 \\
\hline & \multicolumn{4}{|l|}{ Mental health (MH) } \\
\hline & Vitality (VT) & 9a (5) & 1 & 5 \\
\hline \multirow{7}{*}{$S F-6 D$} & \multicolumn{4}{|c|}{ General perception of health (GH) } \\
\hline & Physical function (PF) & $3 a+3 b+3 j(1 a+1 b+1 c)$ & 3 & 6 \\
\hline & Role physical (RP) & $4 c+5 b(2+3)$ & 2 & 2 \\
\hline & Role emotional (RE) & $10(7)$ & 1 & 4 \\
\hline & Social function (SF) & $7+8(4+5)$ & 2 & 9 \\
\hline & Bodily pain (BP) & $9 b+9 f(6 a+6 c)$ & 2 & 10 \\
\hline & Mental health (MH) & 9e (6b) & 1 & 5 \\
\hline
\end{tabular}

Score values range from o-10o. High scores represent better quality of life. SF-36v2 is used for scale score calculation. Physical (PCS) and Mental (MCS) summary measures that belong to SF scales; These summary scores range from 0-100.12,13

\begin{tabular}{|l|l|l|}
\hline SF Scales & PCH & MCH \\
\hline$S F-36 v 2$ and $S F-12$ & PF+RP+BP+GH & VT+SF+RE+MH \\
\hline$S F-8$ & PF+RP+BP+GH & PCH and VT+SF+RE \\
\hline$S F-6 D$ & $\mathrm{PF}+\mathrm{RP}+\mathrm{BP}$ & $\mathrm{VT}+\mathrm{SF}+\mathrm{MH}$ \\
\hline
\end{tabular}

There are four domains of WHOQOLBref scale; the physical health domain, the psychological domain, the social relationships domain, the environmental health domain. This scale doesn't have grand total score. Each section and domain are scored maximum 20 or 100. In this scale general health is evaluated by the first and the second items.

QuickDASH scale is composed of 11 items. It doesn't have any sub dimensions. It is represented with total score. Since this scale measures quality of life arising from upper extremity problems, it is called arm, shoulder and hand questionnaire. WHOQOLBref and QuickDASH scales are used to support SF-36v2 in studying the validity of SF-12, SF-8 and SF-6D.

In Turkey, the SF-36v2 scale, has been found to produce valid and reliable results for rheumatic diseases. ${ }^{14,15}$ In addition, SF-12 scale was used to evaluate the quality of life in people with different sociocultural levels. ${ }^{16}$ In patients with Rheumatoid Arthritis, SF-12 short form was compared with SF-36v2 and showed that it produced valid and 
Determination of the Appropriate Quality of Life Scale for Patients with Rheumatoid Arthritis and Osteoarthritis

reliable results. ${ }^{17}$ In addition, the validity and reliability of SF-12, SF-8 and SF-6D have been investigated in patients with fibromyalgia. ${ }^{18}$ However, Turkey's research conducted in patients with osteoarthritis and rheumatoid arthritis, the validity and reliability of the SF-12, SF-8 and SF-6D has not yet investigated. In this study, the internal consistency, agreement and criterion validity of these short forms were evaluated..

\section{Statistical Analysis}

Descriptive statistics were calculated as Mean \pm SD. Cronbach's alpha coefficient was used for the evaluation of the internal consistency of the scales. The intra-class correlation coefficient was used for relations between item-total score, and for the agreement between SF-36 scale and other short forms. The Spearman Rank correlation analysis were used for evaluation of the relationships between the total scores of the scales. The criterion validity of the short forms (SF) of the quality of life scale were investigated by using WHOQOLBref and QuickDASH scales. Statistical significance level was accepted as $\mathrm{p}<0.05$ and SPSS (ver. 21) program was used in the calculations.

Table 3. Internal consistency results of scale items and sub-dimensions

\begin{tabular}{|c|c|c|c|c|}
\hline Disease & & Scale & $\begin{array}{l}\text { Cronbach's } \\
\text { Internal con }\end{array}$ & \\
\hline \multirow{10}{*}{$\underset{(n=165)}{O A}$} & \multirow{6}{*}{$\begin{array}{l}\text { Internal consistency } \\
\text { between items }\end{array}$} & $\mathrm{SF}-36 \mathrm{v} 2$ & 36 item & 0.829 \\
\hline & & SF-12 & 12 item & 0.715 \\
\hline & & SF-8 & 8 item & 0.814 \\
\hline & & SF-6D & 11 item & 0.707 \\
\hline & & WHOQOLBref & 27 item & 0.936 \\
\hline & & QuickDASH & 11 item & 0.936 \\
\hline & \multirow{4}{*}{$\begin{array}{l}\text { Internal consistency } \\
\text { between } \\
\text { sub-dimensions }\end{array}$} & $\mathrm{SF}-36 \mathrm{v} 2$ & 8 sub-dimensions & 0.697 \\
\hline & & SF-12 & 8 sub-dimensions & 0.733 \\
\hline & & SF-8 & 7 sub-dimensions & 0.775 \\
\hline & & SF-6D & 6 sub-dimensions & 0.776 \\
\hline \multirow{10}{*}{$\begin{array}{c}\text { RA } \\
(n=57)\end{array}$} & \multirow{6}{*}{$\begin{array}{l}\text { Internal consistency } \\
\text { between items }\end{array}$} & SF-36v2 & 36 item & 0.806 \\
\hline & & SF-12 & 12 item & 0.727 \\
\hline & & SF-8 & 8 item & 0.850 \\
\hline & & SF-6D & 11 item & 0.787 \\
\hline & & WHOQOLBref & 27 item & 0.927 \\
\hline & & QuickDASH & 11 item & 0.917 \\
\hline & \multirow{4}{*}{$\begin{array}{l}\text { Internal consistency } \\
\text { between } \\
\text { sub-dimensions }\end{array}$} & SF-36v2 & 8 sub-dimensions & 0.659 \\
\hline & & SF-12 & 8 sub-dimensions & 0.690 \\
\hline & & SF-8 & 7 sub-dimensions & 0.805 \\
\hline & & SF-6D & 6 sub-dimensions & 0.730 \\
\hline
\end{tabular}

\section{Results}

Reliability Analysis of the Scales

\section{(a) Internal Consistency}

Results of internal consistency among sub dimensions and among items of SF-36v2, 
SF-12, SF-8, SF-6Dv2, WHOQOLBref and QuickDASH scales are displayed in Table 3. It is observed that internal consistency among sub dimensions and among items are at a good level both in OA and RA. Because the items were be correlated with one another, it can be said that the items were all measure the same thing.

(b) Agreement of Scale Scores (Repetability)

In OA patients, SF-6D scale showed better agreement at PF, BP and VT

sub-dimensions. In SF-12 scale RP, RE and GH showed higher agreement. In these 6 dimensions the lowest agreement is observed in SF-8. All results are found to be statistically meaningful. In SF, MF sub dimesnions and PCS, MCS summary measures SF-12 and SF-6D scales are found to have similar but better agreement values than SF-8 (Table 4).

Table 4. Agreement of sub-dimensions between scales in OA patients

\begin{tabular}{|c|c|c|c|c|}
\hline & & SF-12 PF & SF-8 PF & SF-6D PF \\
\hline \multirow{2}{*}{$\mathrm{SF}-36 v 2 \mathrm{PF}$} & ICC & 0.661 & 0.731 & 0.831 \\
\hline & $\mathrm{p}$ & $<0.0001$ & $<0.0001$ & $<0.0001$ \\
\hline & & SF-12 RP & SF-8 RP & SF-6D RE\&RP \\
\hline \multirow{2}{*}{$\mathrm{SF}-36 v 2 \mathrm{RP}$} & ICC & 0.790 & 0.430 & 0.571 \\
\hline & $\mathrm{p}$ & $<0.0001$ & 0.007 & $<0.0001$ \\
\hline & & SF-12 BP & SF-8 BP & SF-6D BP \\
\hline \multirow{2}{*}{$\mathrm{SF}-36 v 2 \mathrm{BP}$} & ICC & 0.745 & 0.806 & 0.828 \\
\hline & $\mathrm{p}$ & $<0.0001$ & $<0.0001$ & $<0.0001$ \\
\hline & & SF-12 GH & SF-8 GH & SF-6D GH \\
\hline \multirow{2}{*}{$\mathrm{SF}-36 v 2 \mathrm{GH}$} & ICC & 0.603 & 0.470 & \multirow{2}{*}{$--^{*}$} \\
\hline & $\mathrm{p}$ & $<0.0001$ & 0.007 & \\
\hline & & SF-12 VT & SF-8 VT & SF-6D VT \\
\hline \multirow{2}{*}{$\mathrm{SF}-36 v 2 \mathrm{VT}$} & ICC & 0.535 & 0.670 & 0.697 \\
\hline & $\mathrm{p}$ & $<0.0001$ & $<0.0001$ & $<0.0001$ \\
\hline & & SF-12 SF & SF-8 SF & SF-6D SF \\
\hline \multirow{2}{*}{$\mathrm{SF}-36 v 2 \mathrm{SF}$} & ICC & 0.690 & 0.620 & 0.690 \\
\hline & $\mathrm{p}$ & $<0.0001$ & $<0.0001$ & $<0.0001$ \\
\hline & & SF-12 RE & SF-8 RE & SF-6D RE\&RP \\
\hline \multirow{2}{*}{$\mathrm{SF}-36 v 2 \mathrm{RE}$} & ICC & 0.694 & 0.560 & 0.650 \\
\hline & $\mathrm{p}$ & $<0.0001$ & $<0.0001$ & $<0.0001$ \\
\hline & & SF-12 MH & SF-8 MH & SF-6D MH \\
\hline \multirow{2}{*}{$\mathrm{SF}-36 v 2 \mathrm{MH}$} & ICC & 0.637 & \multirow{2}{*}{$--^{*}$} & 0.626 \\
\hline & $\mathrm{p}$ & $<0.0001$ & & $<0.0001$ \\
\hline & & PCS_SF-12 & PCS_SF-8 & PCS_SF-6D \\
\hline \multirow{2}{*}{ PCS_SF-36v2 } & ICC & 0.858 & 0.792 & 0.862 \\
\hline & $\mathrm{p}$ & $<0.0001$ & $<0.0001$ & $<0.0001$ \\
\hline & & MCS_SF-12 & MCS_SF-8 & MCS_SF-6D \\
\hline \multirow{2}{*}{ MCS_SF-36v2 } & ICC & 0.720 & 0.600 & 0.715 \\
\hline & $\mathrm{p}$ & $<0.0001$ & $<0.0001$ & $<0.0001$ \\
\hline
\end{tabular}


Repetability level of SF-12, SF-8, SF-6Dv2 scales in other words agreement among sub dimension scores is examined. In the evaluation, agreement between each sub dimension of the 3 short forms and the same sub dimension of SF- $36 v 2$ scale is examined. The results for OA and RA is displayed in Table 4 and Table 5. In RA patients, SF-6D scale showed better agreement at BP, VT and SF. In SF-12 scale PF, RP, $\mathrm{GH}$ and RE showed higher agreement. In these 7 dimensions the lowest agreement is observed in SF-8. All results are found to be statistically meaningful. In MH sub dimension SF-12 and SF-6D scales showed similar agreement. For PCS summary measure, agreement of SF-12 found to be slightly higher than that of SF-6D, however, in MCS summary scale both scales showed similar agreement (Table 5).

Table 5. Agreement of sub-dimensions between scales in RA patients

\begin{tabular}{|c|c|c|c|c|}
\hline & & SF-12 PF & SF-8 PF & SF-6D PF \\
\hline \multirow{2}{*}{ SF-36v2 PF } & ICC & 0.801 & 0.555 & 0.789 \\
\hline & $\mathrm{p}$ & $<0.0001$ & 0.002 & $<0.0001$ \\
\hline & & SF-12 RP & SF-8 RP & SF-6D RE\&RP \\
\hline \multirow{2}{*}{$\mathrm{SF}-36 v 2 \mathrm{RP}$} & ICC & 0.785 & $<0.0001$ & 0.647 \\
\hline & $\mathrm{p}$ & $<0.0001$ & 0.008 & $<0.0001$ \\
\hline & & SF-12 BP & SF-8 BP & SF-6D BP \\
\hline \multirow{2}{*}{$\mathrm{SF}-36 v 2 \mathrm{BP}$} & ICC & 0.683 & 0.799 & 0.830 \\
\hline & $\mathrm{p}$ & $<0.0001$ & $<0.0001$ & $<0.0001$ \\
\hline & & SF-12 GH & SF-8 GH & SF-6D GH \\
\hline \multirow{2}{*}{$\mathrm{SF}-36 v_{2} \mathrm{GH}$} & ICC & 0.705 & 0.505 & \multirow{2}{*}{$--^{*}$} \\
\hline & $\mathrm{p}$ & $<0.0001$ & 0.007 & \\
\hline & & SF-12 VT & SF-8 VT & SF-6D VT \\
\hline \multirow{2}{*}{$\mathrm{SF}-36 v 2 \mathrm{VT}$} & ICC & 0.650 & 0.612 & 0.776 \\
\hline & $\mathrm{p}$ & $<0.0001$ & $<0.0001$ & $<0.0001$ \\
\hline & & SF-12 SF & SF-8 SF & SF-6D SF \\
\hline \multirow{2}{*}{$\mathrm{SF}-36 v 2 \mathrm{SF}$} & ICC & 0.670 & 0.652 & 0.686 \\
\hline & $\mathrm{p}$ & $<0.0001$ & $<0.0001$ & $<0.0001$ \\
\hline & & SF-12 RE & SF-8 RE & SF-6D RE\&RP \\
\hline \multirow{2}{*}{$\mathrm{SF}-36 v_{2} \mathrm{RE}$} & ICC & 0.672 & 0.535 & 0.610 \\
\hline & $\mathrm{p}$ & $<0.0001$ & $<0.0001$ & $<0.0001$ \\
\hline & & SF-12 MH & SF-8 MH & SF-6D MH \\
\hline \multirow{2}{*}{$\mathrm{SF}-36 v 2 \mathrm{MH}$} & ICC & 0.639 & \multirow{2}{*}{$--{ }^{*}$} & 0.633 \\
\hline & $\mathrm{p}$ & $<0.0001$ & & $<0.0001$ \\
\hline & & PCS_SF-12 & PCS_SF-8 & PCS_SF-6D \\
\hline \multirow{2}{*}{ PCS_SF-36v2 } & ICC & 0.885 & 0.768 & 0.825 \\
\hline & $\mathrm{p}$ & $<0.0001$ & $<0.0001$ & $<0.0001$ \\
\hline & & MCS_SF-12 & MCS_SF-8 & MCS_SF-6D \\
\hline \multirow{2}{*}{ MCS_SF-36v2 } & ICC & 0.720 & 0.630 & 0.718 \\
\hline & $\mathrm{p}$ & $<0.0001$ & $<0.0001$ & $<0.0001$ \\
\hline
\end{tabular}


Determination of the Appropriate Quality of Life Scale for Patients with Rheumatoid Arthritis and Osteoarthritis

When we evaluated internal consistency and agreement together, we concluded that SF-12, SF-8 and SF-6D are reliable scales for OA and RA patients, also among these 3 scales SF-6D and SF-12 are similar to each other and they give better results than SF-8.

For the PF dimension of SF-36v2 scale SF-8 had the lowest validity among the other 3 scales. The scales that have the strongest relationship with RP sub dimension were SF-12 and SF-6D, respectively. The scales that have the strongest relationship with QuickDASH and WHOQOLBref scales were SF-12 and SF-6D. According to this result, it can be said that the most valid scales for RP dimension are SF-12 and SF-6D. The scales that have the strongest relationship with BP sub dimension were SF-8 and SF-6D. It can be said that the most valid scales for BP sub dimension are SF-8 and SF-6D. SF-6D scale doesn't have the GH sub dimension. That's why, for GH sub dimension, only SF-12 and SF-8 scales' validity coefficients are calculated. SF-12 scale's relationship with the other scale scores is found to be higher than SF-8 scale. The scale that has the strongest relationship with the VT sub dimension is SF-6D. In the other two scales, we found two results.

The sub dimensions of QuickDASH and WHOQOLBref scales and the other 3 scales had similar and statistically meaningful relationship. According to this result, it can be concluded that VT sub dimension can be measured best in a valid way with SF-6D and then SF-12 and SF-8 scales, respectively. SF sub dimension can be measured best in a valid way with SF-6D and then SF-12 and SF-8 scales, respectively The sub dimension that is defined as Role Participation in SF-6D scale is a sum of one item from each of the RP and RE sub dimensions. For this reason, the relationship between RP and RE sub dimensions of SF-36v2 and RP+RE dimensions of SF-6D is examined. For this dimension, it is observed that SF-12 and SF-6D scales gave more valid results than SF-8. Since SF-8 scale doesn't have MH sub dimension, validity coefficients of SF-12 and SF-6D are calculated. Both scales' relationship with MH sub dimension of SF-36v2 scale is found to be at a good level, similar and statistically meaningful (Table 6).

Table 6. The criterion validity results of subscales of SF-12, SF-8 and SF-6D scales

\begin{tabular}{|c|c|c|c|c|c|c|c|c|c|c|c|c|}
\hline \multirow{3}{*}{ PF } & \multicolumn{6}{|c|}{ Osteoarthritis } & \multicolumn{6}{|c|}{ Rheumatoid arthritis } \\
\hline & \multicolumn{2}{|c|}{ SF-12 PF } & \multicolumn{2}{|c|}{ SF-8 PF } & \multicolumn{2}{|c|}{ SF-6D PF } & \multicolumn{2}{|c|}{ SF-12 PF } & \multicolumn{2}{|c|}{ SF-8 PF } & \multicolumn{2}{|c|}{ SF-6D PF } \\
\hline & $\mathbf{r}$ & $\mathbf{p}$ & $\mathbf{r}$ & $\mathbf{p}$ & $\mathbf{r}$ & $\mathbf{p}$ & $\mathbf{R}$ & $\mathbf{p}$ & $\mathbf{r}$ & $\mathbf{P}$ & $\mathbf{r}$ & $\mathbf{P}$ \\
\hline SF-36v2_PF & 0.571 & $<0.001$ & 0.607 & $<0.001$ & 0.728 & $<0.001$ & 0.712 & $<0.001$ & 0.396 & 0.003 & 0.646 & $<0.001$ \\
\hline Quick DASH & -0.490 & $<0.001$ & -0.412 & $<0.001$ & -0.663 & $<0.001$ & -0.302 & 0.031 & -0.285 & 0.042 & -0.468 & .001 \\
\hline Physical health & 0.442 & $<0.001$ & 0.528 & $<0.001$ & 0.651 & $<0.001$ & 0.544 & $<0.001$ & 0.517 & $<0.001$ & 0.537 & $<0.001$ \\
\hline Psychological he & 0.192 & 0.016 & 0.248 & 0.002 & 0.376 & $<0.001$ & 0.235 & 0.103 & 0.148 & 0.310 & 0.171 & 0.241 \\
\hline Social relations & 0.183 & 0.022 & 0.144 & 0.074 & 0.276 & $<0.001$ & 0.218 & 0.132 & 0.015 & .920 & 0.192 & 0.187 \\
\hline Environmental & .244 & 0.002 & 0.208 & 0.009 & 0.317 & $<0.001$ & 0.277 & 0.054 & 0.059 & 0.689 & 0.259 & 0.073 \\
\hline $\mathbf{R P}$ & \multicolumn{2}{|c|}{ SF-12 RP } & \multicolumn{2}{|c|}{ SF-8 RP } & \multicolumn{2}{|c|}{ SF-6D RE+RP } & \multicolumn{2}{|c|}{ SF-12 RP } & \multicolumn{2}{|c|}{ SF-8 RP } & \multicolumn{2}{|c|}{ SF-6D RE+RP } \\
\hline $\mathrm{SF}-36 v 2 \mathrm{RP}$ & 0.657 & $<0.001$ & 0.373 & $<0.001$ & 0.437 & $<0.001$ & 0.654 & $<0.001$ & 0.209 & 0.132 & 0.472 & $<0.001$ \\
\hline QuickDASH & -0.408 & $<0.001$ & -0.265 & 0.001 & -0.386 & $<0.001$ & -0.198 & 0.163 & -0.287 & 0.041 & -0.398 & 0.004 \\
\hline Physical health & 0.313 & $<0.001$ & 0.242 & 0.002 & 0.369 & $<0.001$ & 0.474 & 0.001 & 0.189 & 0.194 & 0.307 & 0.032 \\
\hline
\end{tabular}


Determination of the Appropriate Quality of Life Scale for Patients with Rheumatoid Arthritis and Osteoarthritis

\begin{tabular}{|c|c|c|c|c|c|c|c|c|c|c|c|c|}
\hline th & 167 & 0.037 & 168 & .036 & 0.338 & $<0.001$ & 0.352 & 0.013 & 0.154 & .289 & .192 & 0.185 \\
\hline al relations & 158 & 3 & 8 & 013 & 326 & 0.001 & 0.220 & .129 & .023 & 877 & .184 & .205 \\
\hline aviro & 173 & 0.03 & 163 & 042 & 275 & 0.001 & 400 & .004 & 0.135 & 55 & .187 & 199 \\
\hline $\mathbf{B P}$ & \multicolumn{2}{|c|}{ SF-12 BP } & \multicolumn{2}{|c|}{ SF-8 BP } & \multicolumn{2}{|c|}{ SF-6D BP } & \multicolumn{2}{|c|}{ SF-12 BP } & \multicolumn{2}{|c|}{ SF-8 BP } & \multicolumn{2}{|c|}{ SF-6D BP } \\
\hline $3002 \mathrm{D1}$ & 598 & $<0.001$ & 0.731 & 0.001 & 0.740 & 0.001 & 0.526 & $<0.001$ & 0.734 & $<0.001$ & 0.723 & 0.0 \\
\hline & .523 & $<0.001$ & .440 & $<0.001$ & -0.509 & $<0.001$ & -0.516 & $<0.001$ & $-0.291 \mid$ & .038 & -0.462 & .001 \\
\hline & 560 & 0.001 & 579 & .001 & 608 & D.001 & 594 & 0.001 & 308 & .031 & 494 & .00 \\
\hline$-a_{2}+2$ & 355 & $<0.001$ & 0.336 & 0.001 & 0.278 & $<0.001$ & 0.190 & 0.190 & 0.081 & .578 & .097 & .508 \\
\hline is & 267 & 0.001 & 236 & 0.003 & 0.249 & .002 & 0.115 & 432 & .104 & 475 & .155 & .287 \\
\hline & 316 & . & .272 & 0.001 & 0.215 & 0.007 & 0.145 & 0.319 & .060 & 0.681 & 0.103 & 0.48 \\
\hline & \multicolumn{2}{|c|}{ SF-12 GH } & \multicolumn{2}{|c|}{ SF-8 GH } & \multicolumn{2}{|c|}{ SF-6D GH } & \multicolumn{2}{|c|}{ SF-12 GH } & \multicolumn{2}{|c|}{ SF-8 GH } & \multicolumn{2}{|c|}{ SF-6D GH } \\
\hline$F-26$ & 534 & $<0000$ & 0.438 & .001 & \multirow{6}{*}{\multicolumn{2}{|c|}{ sub-dimension }} & 0.641 & $<0.001$ & 0.500 & 0.001 & \multirow{6}{*}{\multicolumn{2}{|c|}{$\begin{array}{c}\text { No } \\
\text { sub-dimension }\end{array}$}} \\
\hline & -0.481 & 0.001 & .489 & 0.001 & & & -0.319 & 0.023 & -0.389 & 5 & & \\
\hline & .467 & $<0.001$ & 0.569 & $<0.001$ & & & 0.526 & $<0.001$ & 0.559 & $<0.001$ & & \\
\hline Psyc & .273 & 0.001 & 0.409 & 0.001 & & & 0.330 & 0.021 & 0.366 & 0.010 & & \\
\hline-1 & $13^{2}$ & 0.050 & 0.348 & 0.001 & & & 0.299 & 0.031 & 0.205 & 0.158 & & \\
\hline nvi & 199 & 0.013 & 0.293 & $<0.001$ & & & 0.271 & 0.060 & 0.217 & 0.135 & & \\
\hline VT & \multicolumn{2}{|c|}{ SF-12 VT } & \multicolumn{2}{|c|}{ SF-8 VT } & \multicolumn{2}{|c|}{ SF-6D VT } & \multicolumn{2}{|c|}{ SF-12 VT } & \multicolumn{2}{|c|}{ SF-8 VT } & \multicolumn{2}{|c|}{ SF-6D VT } \\
\hline & 540 & $<0.001$ & 0.545 & 0.001 & 0.661 & $<0.001$ & 0.571 & $<0.001$ & 0.475 & .001 & 642 & $<0.00$ \\
\hline Quic & -0.345 & $<0.001$ & -0.401 & $<0.001$ & -0.480 & $<0.001$ & -0.367 & 0.008 & -0.424 & .002 & -0.358 & .010 \\
\hline hysi & 0.470 & $<0.001$ & 0.623 & 0.001 & 0.522 & $<0.001$ & 0.481 & $<0.001$ & 0.348 & .014 & .542 & (2) \\
\hline & 76 & -0.001 & 0.537 & 0.001 & 0.450 & $<0.001$ & 0.323 & .024 & .204 & .159 & 71 & .001 \\
\hline terc & 307 & $<0.001$ & 0.462 & 0.001 & 0.266 & 0.001 & 0.383 & & 0.227 & 110 & .219 & .131 \\
\hline Envil & 217 & 0006 & 450 & $<0.001$ & 0.267 & 0.001 & .366 & 0.008 & .303 & .034 & 0.303 & .03 \\
\hline SF & SF-1 & $12 \mathrm{SF}$ & SF- $\varepsilon$ & C CF & SF-6 & & SF-12 & & SF-8 & & SF-6 & \\
\hline SF-36 & 505 & $<0.001$ & .370 & 0.001 & 0.520 & $<0.001$ & 0.565 & $<0.001$ & 0.480 & 0.001 & .585 & 0.00 \\
\hline inis & .510 & 0.001 & .458 & .001 & 432 & $<0.001$ & -0.365 & 0.008 & -0.348 & .014 & 375 & 80 \\
\hline & 320 & $<0.001$ & 0.255 & 0.003 & 0.330 & $<0.001$ & 0.510 & $<0.001$ & $0.45^{\circ}$ & $<0.001$ & 360 & 0.041 \\
\hline & 290 & $<0.001$ & 0.225 & .004 & 0.280 & $<0.001$ & .318 & 0.026 & 0.305 & .033 & .310 & .027 \\
\hline oci & 35 & 0.003 & .210 & .009 & .215 & .002 & 290 & & 0.205 & .160 & .220 & .100 \\
\hline Envi & 315 & $<0.001$ & 289 & 0.001 & 0.328 & $<0.001$ & .299 & 0.037 & .310 & .030 & 0.210 & 0.030 \\
\hline RE & SF & & $\mathrm{SF}$ & & SF-6 & $+\mathrm{RP}$ & $\mathrm{SF}$ & & SF- & & SF-6D & $+\mathrm{RP}$ \\
\hline & 530 & 年 & 0.434 & 0.001 & 0.496 & $<0.001$ & 0.34 & <o.001 & 0.365 & 0.009 & & .00 \\
\hline & .448 & $<0.001$ & 0.285 & $<0.001$ & -0.386 & $<0.001$ & -0.400 & $<0.001$ & -0.264 & 0.001 & -0.398 & .00 \\
\hline Physi & 301 & $<0.001$ & 0.395 & 0.001 & 0.369 & $<0.001$ & 0.363 & 0.048 & .311 & $<0.001$ & & \\
\hline & 239 & ك & 0.365 & $<0.001$ & 0.338 & $<0.001$ & & & & & & .185 \\
\hline & .261 & & .251 & 0.002 & 0.326 & $<0.001$ & 0.230 & & .051 & .728 & .184 & .205 \\
\hline Envir & 246 & 0.002 & 262 & 0.001 & 0.275 & 0.001 & 0.133 & 0.362 & .041 & 0.781 & 0.187 & .199 \\
\hline MH & SF- & MH & SF & IH & $\mathrm{SF}_{-}$ & MH & SF- & MH & SE & & $\mathrm{F}_{-6}$ & MH \\
\hline SF-36v2 MH & .408 & $<0.001$ & & & 0.514 & $<0.001$ & 0.408 & 0.002 & & & 0.452 & 0.001 \\
\hline QuickDASH & -0.426 & $<0.001$ & & & -0.228 & 0.004 & -0.314 & 0.025 & & & -0.260 & 0.048 \\
\hline hysical health & 0.509 & $<0.001$ & & & 0.333 & $<0.001$ & 0.312 & $<0.001$ & & & 0.360 & 0.0 \\
\hline Psychological he & 0.508 & $<0.001$ & $b-d$ & si & 0.511 & $<0.001$ & 0.575 & $<0.001$ & sub-dim & sio & 0.440 & $<0.001$ \\
\hline Social relations & 0.321 & $<0.001$ & & & 0.265 & 0.001 & 0.279 & 0.044 & & & 0.249 & 0.004 \\
\hline nvironmental health & 0.345 & $<0.001$ & & & 0.407 & $<0.001$ & 0.402 & 0.004 & & & 0.410 & $<0.00$ \\
\hline
\end{tabular}


Determination of the Appropriate Quality of Life Scale for Patients with Rheumatoid Arthritis and Osteoarthritis

\section{Validity results of the Scales}

Criterion validity of SF-12, SF-8 and SF-6D scales is conducted separately and for this purpose, 4 sub dimensions from WHOQOLBref scale and total score of QuickDASH scale are used. Correlation coefficients calculated for each sub dimension of SF scales are displayed in Table 7. When the relationship between SF-12, SF-8, SF6D and SF-36v2 scores are examined, it can be said that SF-12 and SF-6D scale have an aggreement with SF-36v2 results more than SF-8 scale results. This results shows that SF-12 and SF-6D produces valid results. When the validity of PCS and MCS summary measures of SF-scales, SF-12 was the scale that best evaluates the physical and the mental dimensions then came SF-6D and SF-8 scales. Each 3 scale was able to foresee both PCS and MCS very well and in a statistically successful manner. Similar rankings and results among these 3 scales are also observed in their relation with QuickDASH and WHOQOLBref scales (Table 7).

Table 7. The validity results of summary measures of SF-12, SF-8 and SF-6D scales

\begin{tabular}{|c|c|c|c|c|c|c|c|c|c|c|c|c|}
\hline \multirow{3}{*}{ PCS } & \multicolumn{6}{|c|}{ Osteoarthritis } & \multicolumn{6}{|c|}{ Rheumatoid arthritis } \\
\hline & \multicolumn{2}{|c|}{ SF-12 PCS } & \multicolumn{2}{|c|}{ SF-8 PCS } & \multicolumn{2}{|c|}{ SF-6D PCS } & \multicolumn{2}{|c|}{ SF-12 PCS } & \multicolumn{2}{|c|}{ SF-8 PCS } & \multicolumn{2}{|c|}{ SF-6D PCS } \\
\hline & $\mathbf{r}$ & $\mathbf{p}$ & $\mathbf{r}$ & $\mathbf{p}$ & $\mathbf{r}$ & $\mathbf{p}$ & $\mathbf{r}$ & $\mathbf{p}$ & $\mathbf{r}$ & $\mathbf{p}$ & $\mathbf{r}$ & $\mathbf{p}$ \\
\hline $\mathrm{SF}-36 v 2 \mathrm{PCS}$ & 0.797 & $<0.001$ & 0.735 & $<0.001$ & 0.806 & $<0.001$ & 0.842 & $<0.001$ & 0.675 & $<0.001$ & 0.745 & $<0.001$ \\
\hline QuickDASH & -0.626 & $<0.001$ & -0.548 & $<0.001$ & -0.644 & $<0.001$ & -0.437 & 0.001 & -0.412 & 0.003 & -0.534 & $<0.001$ \\
\hline Physical health & 0.576 & $<0.001$ & 0.650 & $<0.001$ & 0.658 & $<0.001$ & 0.695 & $<0.001$ & 0.539 & $<0.001$ & 0.550 & $<0.001$ \\
\hline Psychological health & 0.315 & $<0.001$ & 0.390 & $<0.001$ & 0.406 & $<0.001$ & 0.366 & 0.010 & 0.254 & 0.078 & 0.181 & 0.213 \\
\hline Social relations & 0.250 & 0.002 & 0.309 & $<0.001$ & 0.350 & $<0.001$ & 0.381 & 0.005 & 0.260 & 0.055 & 0.375 & 0.006 \\
\hline Environmental health & 0.304 & $<0.001$ & 0.315 & $<0.001$ & 0.331 & $<0.001$ & 0.366 & 0.010 & 0.115 & 0.432 & 0.219 & 0.131 \\
\hline MCS & \multicolumn{2}{|c|}{ SF-12 MCS } & \multicolumn{2}{|c|}{ SF-8 MCS } & \multicolumn{2}{|c|}{ SF-6D MCS } & \multicolumn{2}{|c|}{ SF-12 MCS } & \multicolumn{2}{|c|}{ SF-8 MCS } & \multicolumn{2}{|c|}{ SF-6D MCS } \\
\hline $\mathrm{SF}-36 v 2 \mathrm{MCS}$ & 0.531 & $<0.001$ & 0.519 & $<0.001$ & 0.525 & $<0.001$ & 0.476 & $<0.001$ & 0.360 & 0.010 & 0.424 & $<0.001$ \\
\hline QuickDASH & -0.511 & $<0.001$ & -0.462 & $<0.001$ & -0.597 & $<0.001$ & -0.445 & $<0.001$ & -0.332 & 0.017 & 0.404 & 0.006 \\
\hline Physical health & 0.480 & $<0.001$ & 0.640 & $<0.001$ & 0.486 & $<0.001$ & 0.405 & 0.004 & 0.389 & 0.006 & 0.439 & 0.002 \\
\hline Psychological health & 0.471 & $<0.001$ & 0.510 & $<0.001$ & 0.294 & $<0.001$ & 0.470 & 0.001 & 0.311 & 0.022 & 0.403 & 0.007 \\
\hline Social relations & 0.444 & $<0.001$ & 0.418 & $<0.001$ & 0.443 & $<0.001$ & 0.315 & 0.027 & 0.221 & 0.100 & 0.357 & 0.010 \\
\hline Environmental health & 0.454 & $<0.001$ & 0.426 & $<0.001$ & 0.455 & $<0.001$ & 0.338 & 0.018 & 0.200 & 0.140 & 0.320 & 0.020 \\
\hline
\end{tabular}

\section{Discussion}

Patients might differ in terms of the significance they attribute to the health conditions that they have. When treatments are evaluated, it is important to consider patients' preferences for specific health results. That's why, measuring the quality of life will 
evaluate the patients' health as a whole. ${ }^{1}$ In OA and RA, which is the most common forms among rheumatologic diseases, in addition to clinical, laboratory and radiological evaluation, evaluating the quality of life will be able to reveal unidentified problems, treatment plan will be better arranged, benefits and harms of health care services will be presented better. ${ }^{2,5}$

While using health quality of life scales in clinical practice, it is observed that some scales are well-known but some others aren't, some can be interpreted but others can't, some are long and others are short and lastly coding and scores are different. For this reason, health quality of life scales that can be better interpreted, are reliable and valid, can reach accurate results in a short time are more preferred in clinics. We have conducted this research to identify the scales that measure quality of life better and in a short time in OA which is one of the most common disease among rheumatic diseases and which causes significant disability, and in RA which causes progressive damage in cartilage and bone and causes severe functional restrictions and is also common. 4,6

SF-36 is a widely-used quality of life scale. It evaluates quality of life from different aspects. It has been adapted to several different cultures and languages and it has been found reliable. It doesn't aim only one disease, so it can be used in all chronic diseases. To have this widely-used form completed in a short time, there are shorter forms of it: SF-12, SF-8, SF-6D. However, it has been found out that the short forms aren't used as much as the long form and reliability and validity of these forms aren't researched in our country. ${ }^{1-12}$

Level of income, education, age and gender might directly affect the results quality of life. Since the relationship between age and scale scores are meaningful for both disease groups in our study, we found that SF scores drop as age goes up and they increase as the level of education increase as well. When gender is in question, we found that SF scores are higher in men. In RA and OA patients, the strongest relationship with the GH sub dimension of SF-36 is found in SF-12 scale. General Health sub-dimension on the SF-12 scale do not have limit the time period. On the SF-8 scale, however, the patient's General Health status in the past week are questioned. But physical, emotional and stressful situations that the patients experience during the last one week might affect holistic evaluation of General Health. SF-6D doesn't include this sub-dimension.

When the study findings were examined, the physical function of the patients was best defined by SF-6D in the OA group and by SF-12 in the RA patients. SF-dimension in SF-6D is evaluated in detail under three headings. It is an accurate evaluation because it evaluates all functions. In SF-8, however, since examples in the questions are directed at a specific part of the body, it might have caused the patients to misunderstand.

The strongest relationship with the RP sub-dimension of SF-36 in RA and in OA, is found in SF-12 scale. In SF-12 scale, RP is asked in a way that the patient can express himself/herself better. Actually, they all make the same enquiry. Patients might have better grasped more concrete answers such as "less than I wanted" in SF-12. However, 
Determination of the Appropriate Quality of Life Scale for Patients with Rheumatoid Arthritis and Osteoarthritis

they might have difficulty in understanding more abstract answers such as "none, very little, severe" in SF-6D and SF-8.

The strongest relationship with the pain dimension of SF-36 in RA and OA, is found in SF-6D. Pain inquiry of SF-6D includes each of the one item in SF-12 and SF-6 scales. That's why, it has more comprehensive pain inquiry.

In RA and OA, the strongest relationship with the VT sub dimension of SF-36 is found in SF-6D scale. In SF-12 and SF-8 scales, the inquiry is directive and insufficient because patients cannot accurately answer the question: "Have you been constantly feeling energetic for the last four weeks?" For this reason, the inquiry is not accurate. The state of feeling energetic might change with in a few days or even hours. In SF-6D scale, however, the inquiry of the state of being energetic includes the change in time. Therefore, it is a more accurate inquiry.

The strongest relationship with the RE sub dimension of SF-36 in RA and OA, is found in SF-12 scale. Since there are yes/no items in SF-12 scale, it was easier for the patents to answer the items. In SF-8 and SF-6D, however, the patients might have had difficulty in answering the emotional item with five answer choices.

In addition the strongest relationship with the social function sub dimension of SF-36 in RA, is found in SF-6D and in OA, both in SF-6D and SF-12. SF-6D and SF-12 scales evaluates the social function in a similar way. In these two scales, social function evaluates physical and emotional state together. Difficulties that are caused by physical problems effect patients' emotions. Since physical and emotional state effect social function together, this is a better inquiry. The inquiry in SF-8 scale is not a kind of inquiry that affects social functions caused by physical problems. The statement "your personal and emotional problems" in the item contains only the emotional domanin. It does not item the ones that depend on physical problems. This causes social function to be evaluated only in one way.

The highest compatibility with MH sub dimension of patients is found with SF-6D and SF-12 scales. Since SF-8 doesn't have MH sub dimension, we couldn't evaluate it. That psychological dimension cannot be determined in these patients is a deficiency. Since these diseases cause psychological defects, making psychological evaluations will make it possible for the patients to get psychologyical treatment. This will affect the course of the treatment.

In OA and RA, the hightest compatibility with summary measure of the mental dimensions (MCS) of SF-36 scale is found in SF-6D and SF-12. The lowest compatibility in all dimenions was with SF-8. That SF-8 scale doesn't have MH sub dimension shows that its mental dimensions are more inadequate. Social function sub dimension inquiry includes emotional domain that doesn't depend on physical problems. This causes social function to be evaluated ony in one way. In RE sub dimension, patients cannot express themselves clearly. In VT sub dimension, the inquiry is directive and insufficient.

The strongest relationship with the summary measure of physical dimension (PCS) of SF-36 in OA is found in SF-6D and SF-12 scales and in OA, the highest compatibility is 
Determination of the Appropriate Quality of Life Scale for Patients with Rheumatoid Arthritis and Osteoarthritis

observed with SF-12. In SF-8, physical dimensions were less effective than SF-6D and SF-12 scales. RP sub dimension is less effective because of vague and abstract inquiry. Pain inquiry with one item is insufficient because chronic pain is in the foreground in OA and RA patients. Since PF sub dimension is directed at only one part of the body, it is less effective on patients. GH evaluation hasn't evaluated patients' health in a holistic way, instead it focused more on their health in the last one week.

In conclusion, scientific questions cannot be answered unless quality of life is measured in clinical research[1]. Besides, in outpatient follow-ups of OA and RA, which are chronic diseases that cause disability, SF-6D and SF-12 scales can be used because they are effective and valid. That SF-8 scale is not as effective as SF-12 and SF-6D in all dimensions limits its usage. As a result, when all evaluations that are made for validity and reliability are considered, in OA and RA patients, SF-12 and SF-6D scales can be used in place of SF-36v2 to measure quality of life. SF-8 scale has also given reliable and valid results, however, it is not better than the others.

\section{References}

1. Fitzpatrick R, Fletcher A, Gore S, Jones D, Spiegelhalter D, Cox D. Quality of life measures in healthcare. I: Applications and issues in assessment BMJ 1992;305:1074-7.

2. Conaghan PG, Dickson J, Grant RL; Guideline Development Group. Care and management of osteoarthritis in adults: summary of NICE guidance. BMJ 2008;336:502-3.

3. Regier NG, Parmelee PA. The stability of coping strategies in older adults with osteoarthritis and the ability of these strategies to predict changes in depression, disability, and pain. Aging Ment Health 2015;19:1113-22.

4. Hurkmans EJ, Jones A, Li LC, Vliet Vlieland TP. Quality appraisal of clinical practice guidelines on the use of physiotherapy in rheumatoid arthritis: a systematic review. Rheumatology (Oxford) 2011;50:1879-88.

5. Pincus T, Kavanough A, Sokka T. Benefit/risk of therapies for rheumatoid arthritis: under estimation of the benefit/risk of therapies. Clin Exp Rheumatol 2004;25:2-11.

6. Hatoum HT, Rosen JE, Fierlinger AL, Lin SJ, Altman RD. Assessment of the health-related quality of life impact of EUFLEXXA (1\% Sodium Hyaluronate) using short form 36 (SF-36) data collected in a randomized clinical trial evaluating treatment of osteoarthritis knee pain. Pharm Anal Acta 2014;5:1-5.

7. Jenkinson C, Stewart-Brown S, Petersen S, Paice C. Assessment of the SF-36 version 2 in the United Kingdom. J Epidemiol Community Health 1999;53: 46-50.

8. Lefante JJ, Harmon Jr GN, Ashby KM, Barnard D, Webber LS. Use of the SF-8 to assess health-related quality of life for a chronically Ill, low-income population participating in the central Louisiana medication access program. Qual Life Res 2005;14:665-73.

9. Muenning P, Bounthavong M. Cost Effectiveness Analysis in Health: A Practical Approach. $2^{\text {nd }}$ ed., London, UK: A Wiley Brand; 2016;65-100.

10. Eser S, Saatlı G, Eser E, Baydur H, Fidaner C. The Reliability and Validity of the Turkish Version of the World Health Organization Quality of Life Instrument-Older Adults Module (WHOQOL-Old). Turkish Psychiatry Journal 2010;21:37-48.

11. Macdermid JC, Khadilkar L, Birmingham TB, Athwal GS. Validity of the QuickDASH in patients with shoulder-related disorders undergoing surgery. Journal of Orthopaedic \& Sports Physical Therapy 2015;45:25-36.

12. Ware JE, Snow KS, Kosinski M, Gandek B. SF-36 Health Survey Manual and Interpretation Guide. Boston, USA: New England Medical Center; 1993;1-20.

13. Ąre JE, Kosinski M, Keller SD. SF-36 Physical and mental health summary scales: A Users' Manual. Boston, USA: New England Medical Center; 1994:1-20. 
Determination of the Appropriate Quality of Life Scale for Patients with Rheumatoid Arthritis and Osteoarthritis

14. Koçyiğit H, Aydemir Ö, Fișek G, Ölmez N, Memiş A. Kısa Form-36 (KF-36)'nın Türkçe versiyonunun güvenilirliği ve geçerliliği: Romatizmal hastalığı olan bir grup hasta ile çalışma. İlaç ve Tedavi Dergisi 1999;12:102-6.

15. Kaya BB, İçağasıoğlu A Romatoid artritli hastalarda Türkçe kısa form 36'nın (SF-36) güvenilirlik ve geçerliliği. J Surg Med 2018;2(1):11-6.

16. Pan Korur A. Adana İl Merkezinde Yașayan Farklı Sosyokültürel Grupların Sağlık Hizmetlerini Kullanma Davranışlarının Değerlendirilmesi. Tıpta Uzmanlık Tezi, Çukurova Üniversitesi Tıp Fakültesi, Aile Hekimliği AD, Adana; 2010.

17. Hurst NP, Ruta DA, Kind P. Comparison of the MOS Short Form-12 (SF12) Health Status Questionnaire with the $\mathrm{SF}_{3} 6$ in patients with Rheumatoid Arthritis. British Journal of Rheumatology 1998;37:862-9.

18. Ataoğlu S, Ankaralı H, Ankaralı S. Fibromiyalji hastalarının yaşam kalitesini değerlendirmede kullanılan ölçeklerin karşılaștırılması. Anadolu Kliniği Tıp Bilimleri Dergisi 2017;22(2):85-94. 